\title{
Science panel's report could end whaling ban
}

London \& Tokyo. Next week the scientific committee of the International Whaling Commission (IWC) is expected to complete work on a document that makes the case for the lifting of a ten-year moratorium on commercial whaling. But a new French proposal to turn a portion of the southern ocean into a whale sanctuary may scuttle any attempt to restart commercial whaling.

The IWC, which meets later in the month in Glasgow, is bound to regulate the conservation and utilization of whale stocks on the basis of scientific findings. The moratorium was put in place in 1982 so that the perceived inadequacy of the science could be set right. Although there were loopholes that allowed some whaling to continue under the provision of research, the numbers caught were relatively small and bodies opposed to whaling felt that the scientific task was so complex that the moratorium could be extended indefinitely. This situation persisted past the IWC's original deadline of 1990.

However, it became clear last year that the scientific committee was close to completing its work on what is called a Revised Management Procedure (RMP). That is when things started to heat up.

In March, the scientific committee met in Copenhagen to iron out most of the existing problems at the core of the RMP, and to answer the IWC's outstanding queries. The management procedure sets out what data need to be collected and how they must be analysed in order to establish how many whales can be caught without threatening their survival.

Although there are different implementation rules for different stocks and extra procedures for multi-stock situations that still need to be resolved, the RMP is ready to be applied to the now well-documented stocks of Minke whales in the North Atlantic and the seas of the Southern Hemisphere. It is within these populations that nations such as Japan, Iceland and Norway want to resume whaling.

Few doubt that the RMP will be presented to the IWC meeting, which begins on 29 June. In recent years the scientific committee has drawn so much attention from both sides of the whaling debate that it is perhaps more balanced than the IWC itself.

What will happen at the main IWC meeting is less predictable, however. Despite the precept that the decisions should be based on science, the determining factors are likely to be political. The countries whose objections to whaling are essentially ethical have little room to manoeuvre in terms of extending the moratorium. There are still matters such as inspection and observation proce- dures to be finalized, which could prevent commercial whaling for another couple of years, but attention is likely to switch to ways of limiting the extent and economic viability of the resumed commercial whaling.

Chief among these moves is a proposal from the French government that the waters south of $40^{\circ} \mathrm{S}$ should be indefinitely designated a whale sanctuary. This is presented as a scientifically motivated plan, as indeed it must be because the IWC does not permit sanctuaries to be established merely to invalidate catch limits.

There is a great deal of scientific background to the proposed sanctuary, the essential element being that it will contribute to the "rehabilitation of the Antarctic marine ecosystem". It would reinforce and complement other conservation measures, in particular the protection of all baleen whales in the Southern Hemisphere and the sperm whales in their feeding grounds.

Fuzuko Nagasaki, executive director of the Cetacean Research Institute in Tokyo and a member of the Japanese delegation, believes that the sanctuary is a "very political" proposal and that it has "no scientific basis". "No whaling, not even scientific whaling, could be carried out", says Nagasaki.

The IWC's rules of sanctuary also exclude the killing of whales for scientific purposes - a much debated loophole that pressure groups argue has allowed commercial whaling elsewhere under the guise of science.

Nagasaki says that the Japanese government is trying to stop the French proposal by lobbying the IWC member nations before the meeting. But if there is a vote, he

\section{IMAGE UNAVAILABLE FOR COPYRIGHT REASONS}

\section{Humpback whale off Newfoundland, Canada}

suspects that the French could obtain the 75-per-cent majority needed to carry the proposal. If that happens, Nagasaki says, Japanese legislators are likely to call for Japan to leave the IWC.

It is possible that a strong research procedure built into the sanctuary plan could help carry it through the IWC, although at present the French proposal contains only a suggestion that the scientific committee be asked to look into the matter. The outcome could hinge on attracting the support of Australia, New Zealand and the South American countries whose territorial waters impinge on the proposed sanctuary.

Japan has lost an important ally in Iceland, which has announced its intention to leave the IWC at the end of June and will not be voting in the meeting this year. Iceland may have pushed itself into a corner by leaving the IWC: to resume whaling and remain within the United Nation's Law of the Sea, it has to co-operate with the relevant international organizations - until recently only the IWC. However, in April it became one of the founding members of the North Atlantic Marine Mammal Commission along with Norway, Greenland and the Faeroe Islands.

The new commission has said it intends to manage only small cetaceans such as small whales and dolphins. But the potential exists to set catch limits on larger whales.

Ian Mundell \& David Swinbanks

\section{France welcomes British physicists}

London. British nuclear structure physicists, soon to be deprived of an accelerator to work with in their own country, can now transfer their affections to France. An agreement signed by Sir Mark Richmond, chairman of the Science and Engineering $\mathrm{Re}$ search Council (SERC), and Claude Detraz, director of the Institut National de Physique Nucleaire et de Physique des Particules, provides a framework for collaboration in nuclear structure physics.

In general, the agreement gives French scientists access to British funds and equipment and British scientists a place to work. Since the closure next year of the Nuclear Structure Facility (NSF) at Daresbury was announced in 1991 as a cost-cutting measure, international collaboration has been seen as the only salvation. The SERC hopes that the agreement will ease that process.

Eurogram, an ultra-sensitive gamma-ray detector built at the NSF, will be used for the first project under the new agreement. Part of an existing collaboration, it was already due to be transferred in 1993 to the Vivitron tandem Van de Graaff generator being built in Strasbourg. The second project is likely to involve Charissa, an NSF-based array for detecting charged particles. It may also travel to France, although other sites in Europe and Australia are still being considered.
Ian Mundell 